\title{
Effects of Career Placement by KUCCPS among the Undergraduate Students in Public Universities in Kiambu County, Kenya
}

\author{
Karanja Joseph Ndung' $u^{1}$, Rose Obae ${ }^{2}$ \\ ${ }^{I}$ PhD Student, Department of Education Administration and planning, University of Nairobi, Kikuyu Campus, Thika, Kenya \\ ${ }^{2}$ Senior Lecturer, Department of Education Administration and planning, University of Nairobi, Kikuyu Campus, Thika, Kenya
}

\begin{abstract}
The study assessed the effects of career placement by KUCCPS to students' career choice and the career guidance information by KUCCPS on students' degree programme selection process in the public universities in Kiambu County, Kenya. The target population was 3000 first year students from Kenyatta University, Jomo Kenyatta University of Agriculture and Technology (JKUAT) and University of Nairobi. A sample size of 900 students was obtained. Data collection was done using questionnaires, while data analysis was done using descriptive statistics. Findings showed that $82.8 \%$ of the students had applied for most famous degree programmes (Health/Biological sciences, Law, Engineering/architecture/ building and construction, Computer related courses, Business related courses and Statistics/Accounting/commerce) showing a high preference of these courses. But after placement majority of the students (72.9\%) were placed in Art related courses different from what they had not applied for. From the Pearson product correlation coefficient which was $\mathbf{- 0 . 7 5}$ and the scatter diagram, it clear that there was strong negative correlation between what the students had applied for and what they were placed for. KUCCPS did not place most of the students on degree programmes of their choice and interest, but they were placed in different programmes. Moreover, $67.7 \%$ of the students agreed that they were not able to access KUCCPS website for career guidance and information. To minimize placement challenges, KUCCPS should be working closely with the labour market each and every year to establish the skill gap, so that it place students to fill the gap in future but not totally relying on its laid down policy which should be dynamic and not statics or fixed. With this kind of strategy most students will benefit and will be satisfied with the placement process. The career and guidance teachers should be empowered and trained with career guided skills, knowledge and provided with enough resources by KUCCPS to carry out effective career guidance services at secondary schools level before placement in the University.
\end{abstract}

Key words: Kenya Universities and Colleges Central placement Service (KUCCPS), Placement, Career choice, Skill gap and Knowledge Accumulation.

\section{INTRODUCTION}

$\mathrm{K}$ UCCPS was established in pursuant to its mandate as provided by the University Act, 2012, section 56(1) (a) to coordinate the placement of government-sponsored students to Kenyan Universities and colleges; develop and implement career guidance programmes; disseminate information on available programmes; and collect and retain data relating to university and colleges placement. Admission in Kenyan Universities is done by Kenya Universities and Colleges Central Placement Service (KUCCPS), which is the body given the mandate of placing O-level students to different careers in both private and public universities. Students who complete O-level and manage to score grade C+ to grade A plain are placed into various degree programs as per the cluster laid down by KUCCPS. In Kenya admission of students into universities is a highly contested exercise due to limited chances available for each degree programme and also constrained facilities in various faculties of universities ( Porter \& Umbach, 2006).

University education is a critical component of human development, which provides high-level skills necessary for every labour market. Career placement and implication have become major factors in knowledge accumulation, contributing to economic development. Hence, students' choice in career placement in higher education has gained greater importance because higher education has become competitive and market- oriented. Higher education enables individuals to expand their knowledge and skills, express their thoughts clearly, grasp concepts and theories and increase their understanding of the world and society (Gibson \& Mitchell, 2003).

The choice of degree programme that students make when joining public universities is one of the series of decisions made in the process of career development, Agrey and Lampadan (2014). This is the major turning point in the students' lives which not only is a start to workplace readiness, but also establishes the student in a career path that opens as well as closes opportunities (Gibson \& Mitchell, 2003). Upon the completion of secondary school education students apply for admissions to universities in Kenya through the Kenya Universities and Colleges Central Placement Service (KUCCPS). Selection and placement to universities is done under a common framework that ensures students access university education, based on academic merit for institutional based undergraduate students (KUCCPS, 2014).

Students admitted through this body get funding from the government and study under regular programme (Module 1). A significant number of students who secure admission into 
the universities through the placement service are neither offered degree programmes of their choice nor placed in their preferred university (Muindi, 2011). With policies laid down by KUCCPS governing career placement such as cut-off points, course capacity based on the number of universities offering the course and the number of students required and also their mean grades, majority of students don't get a chance to secure a degree course of their choice. According to Mutero (2001) the self-sponsored (Module II programme) offers the students the advantage of pursuing degree programme related to their career interests and also study in their preferred university with the possibility of earlier completion of their programmes as compared to those in the regular module. Taking into consideration the apparent increase in youth unemployment, mid-life career changes, frequent job lay-offs, restructurings and high job turnovers, a major concern is what might be the long term implications of unsuitable career choices on Kenyan students and consequently on the job market. It is against this background that the study sought to establish the effects of career placement by KUCCPS among the undergraduate students in the public Universities in Kiambu County.

\subsection{Research Problem}

The students who carry out the career task of choosing a degree programme successful are able to handle future careers tasks, while those who fail are discontented and experience difficulties in handling future career tasks. Some of the difficulties that can be experienced in later career tasks are observed when several years later the students graduate and find no jobs related to the degree programmes or take up jobs for which they are not qualified or overqualified. In Kenyan public Universities, not all students admitted under KUCCPS get their preferred degree programmes. Consequently some students are either satisfied or dissatisfied with the outcome of their degree choices. Various factors have been known to influence students' degree choice and university placement. The study sought to find out the effects of career placement by KUCCPS among the undergraduate students in the public universities in Kiambu County, Kenya.

\subsection{Objectives of the Study}

- To determine the influence of career placement by KUCCPS to students' career choice in the public universities in Kiambu County, Kenya.

- To investigate the career guidance information from KUCCPS on students' degree programme selection process in the public universities in Kiambu County, Kenya.

\subsection{Research Questions}

- How does career placement by KUCCPS influence the students' career choice in public universities in Kiambu County, Kenya?
- Do the career guidance information by KUCCPS able to reach students in their career selection process in public universities in Kiambu County, Kenya?

\subsection{Hypothesis of the Study}

- Career placement by KUCCPS significantly influences the students' career choice in public universities in Kiambu County, Kenya.

- Career guidance information by KUCCPS significantly affects students' degree programme selection process in the public universities in Kiambu County, Kenya

\subsection{Scope of the study}

The study covered the effects of career placement by Kenya universities and colleges central placement service among the undergraduate students in the public universities. Furthermore, the outcome of the synthesis of career and self assessment, that is, a match between an individual's academic potentials, attitudes, talents, interests, personality, values and expectations based on an individual career choices and coming up with what suits a person best at that point in time.

\section{LITERATURE REVIEW}

The choice of degree programme that young people make when joining universities is one of the series of decisions made in this process of career development, (Alfed-Davidson, 2009). This is the major turning point in the student's lives which not only is a start to workplace readiness, but also establishes the student in a career path that opens as well as closes opportunities (Swan, 1998). This decision is influenced by many factors, including career interests, educational policies, academic potential, family background, social economic factors, peers influence, career information, personality, employment opportunities and life context (Mc Mohan, 2014). Ghase (2002) states that some individuals find themselves later in occupations never understanding what propelled them in that particular direction. Others make career decision by taking path of least resistance, for example following a career path advocated by their parents or following in the footsteps of elder siblings.

Career guidance is an inclusive term that is used to describe a range of career interventions including career education, career information and career counseling (Kidd, 2007; Savickas, 2005) The major goal of offering career guidance is to help students move from general understanding of life and work to a specific understanding of realities of life, learning and work options that are open to them (Mc Mohan, 2014. Career guidance enhances the career development of an individual throughout the life span (Brown \& Associates, 2002). The career guidance services provided to students should focus on provision of career information through a variety of resources and activities (Mutie \& Ndambuki, 2004). Career information involves provision of accurate and usable facts concerning careers that state the entry and training 
requirements, employment opportunities, nature and conditions of work, advancement opportunities, salary and benefits, trends and outlook, Banks-Santilli (2014). According to Gaffner and Hazler (2002), lack of adequate career information and self awareness was related to indecisiveness and career indecision among students entering college.

\section{METHODOLOGY}

\subsection{Research design}

The research design adopted for this study was quantitative and qualitative design. The blending of qualitative and quantitative methods in this study neutralized bias, sought convergence of results and produced final product which highlighted the significant contribution of both approaches, where both, therefore used numeric and word data easily.

\subsection{Target population}

The sample size for the study comprised of students from three universities; Kenyatta University, Jomo Kenyatta University of Agriculture and Technology (JKUAT) and University of Nairobi. The population included 1200 students from University of Nairobi (UON admission Office, 2018), Jomo Kenyatta University of Agriculture and Technology 800 students (JKUAT Admission Office, 2018) and Kenyatta university 1000 students (KU admission Office, 2018), all from different schools. The total sample size was 3000 respondents, as represented in Table 1.

Table 1: Target Population

\begin{tabular}{|c|c|}
\hline University & Target population \\
\hline University of Nairobi & 1200 \\
\hline Kenyatta University & 1000 \\
\hline JKUAT & 800 \\
\hline TOTAL & 3000 \\
\hline
\end{tabular}

\subsection{Sample size and Sampling procedure.}

In this study stratified random sampling was employed. Whereby, 30 percent of the target population was used (Mugenda \& Mugenda, 2003), giving rise to a sample size of 900 respondents. The sample selection procedure is displayed in Table 2.

Table 2: Sample size and sampling procedure

\begin{tabular}{|c|c|c|c|}
\hline University & $\begin{array}{c}\text { Target } \\
\text { Population }\end{array}$ & $\begin{array}{c}\text { Sample } \\
\text { Percentage }\end{array}$ & Sample Size \\
\hline $\begin{array}{c}\text { University of } \\
\text { Nairobi }\end{array}$ & 1200 & 30 & 360 \\
\hline Kenyatta University & 1000 & 30 & 300 \\
\hline JKUAT & 800 & 30 & 240 \\
\hline TOTAL & 3000 & & 900 \\
\hline
\end{tabular}

\subsection{Research instruments}

The data collection instrument included questionnaires administered to students in the school of education. The questionnaire items comprised of both close ended and openended questions, as well as matrix items that gave the advantage of collecting both qualitative and quantitative data, in addition to generating maximum information. Questionnaire was to collect data on the career guidance information by KUCCPS on students' career selecting process and the influence of career placement by KUCCPS to students' career choice in public universities.

\subsection{Data analysis technique}

The scientific package of social sciences (SPSS) computer package version was used as a 'toolbox' to analyze data related to objectives. Qualitative data was analyzed by use of mean, standard deviations, the ranges, percentages, pie charts, bar graphs, and frequency polygons. Descriptive statistics gave general opinion with regard to the career guidance and placement service done by KUCCPS. Quantitative data was analyzed using inferential statistics whereby the data collected was used to test hypotheses, also the specific tools that was employed under inferential statistics are ANOVA, independent sample t-test and regression analysis.

\section{RESULTS AND DISCUSSION}

\subsection{Demographic Characteristics of the Respondents}

The demographic characteristics presented in this section include; response rate and sample composition, gender, degree programmes, mean grades and distribution of grades per degree programme.

Three Universities in Kenya were selected to constitute the study sample of the study. The researcher sought quantitative and qualitative data from 900 first year students. The response rate by University and the percentage of the sample is represented in Table 3 .

Table 3: Response Rate and Sample Composition

\begin{tabular}{|c|c|c|}
\hline University & Frequency & $\begin{array}{c}\text { Sample composition } \\
\text { percentage }\end{array}$ \\
\hline University of Nairobi & 349 & 38.8 \\
\hline Kenyatta University & 288 & 32.0 \\
\hline JKUAT & 228 & 25.3 \\
\hline TOTAL & 865 & 96.1 \\
\hline
\end{tabular}

The overall response rate of the respondents for the study was 96.1 percent. The response rate was considered adequate and sufficient for analysis and to make conclusions. The sample of respondents comprised of both male and female students in the universities. The male subjects that participated in the study were $492(56.9 \%)$ and the female subjects were 373 $(43.1 \%)$.

\section{Gender of the Respondents}

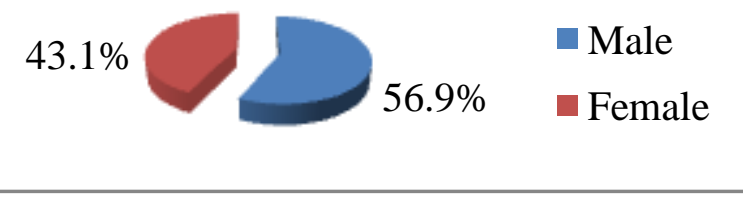

Figure 1: Gender of the Respondents 
Despite the affirmative action that was adopted by Kenyan government as stated by Onsongo (2009), which was believed to change the enrolment ratio of both male and female students in joining Universities. Ng'ang'a (2014) concurs with the distribution of gender according to the report in which he stated that at least $60 \%$ of the students enrolled in Universities in 2012 were males and $40 \%$ for female. According to 2018 enrolment the percentage is almost the same, there is no significant change in enrollment. Onsongo (2011) observed that the gender equity interventions which were implemented in the Universities by lowering of entry points for girls who applied for admission, had not resulted in any significant increase in female students' enrolment.

\subsection{To Determine the Influence of Career Placement by KUCCPS to students' Career choice in Public Universities.}

4.2.1The distribution of grades among the various degree programmes in 2018 that were sampled from students in those three Universities.

Table 4: Distribution of Students Mean Grades as placed by KUCCPS to various Degree progammes in 2018.

\begin{tabular}{|c|c|c|}
\hline KCSE Mean Grade & Frequency & Percentage \\
\hline A & 30 & 3.5 \\
\hline A- & 104 & 12.0 \\
\hline B+ & 146 & 16.9 \\
\hline B & 214 & 24.7 \\
\hline B- & 203 & 23.5 \\
\hline C+ & 168 & 19.4 \\
\hline TOTAL & 865 & 100 \\
\hline
\end{tabular}

Table 4 clearly shows that majority of students 24.7 percent scored B, 23.5 percent had scored B, 19.4 percent had scored C+, 16.9 percent had scored $\mathrm{B}+, 12.0$ percent had scored A-, and the least number of students had scored $\mathrm{A}(3.5 \%)$ from the three Universities, which is an indicator that grade A is not a common grade to many students. On average majority of students scored between grade B- and B+, which is a good grade that can allow any student to secure a degree programme of his/her choice in the University. Despite the students attaining the minimum requirement from the three universities, majority of the students were not satisfied with the placement, since they did not secure degree programme of their choice having met the minimum requirements.

\subsubsection{Distribution of students by Degree programme of their choice before placement by KUCCPS.}

The student sample was further stratified into various degree programmes in the public Universities. Out of 24 clusters for degree programmes as prescribed by KUCCPS policy guidelines for (2013/2014), the clustered were further narrowed down into 11 categories, according to the required subjects, area of specialization and cut-off points. Table 5 shows distribution of students by degree programme as they had applied through KUCCPS Before placement.

Table 5: Distribution of students by Degree programmes as applied through KUCCPS

\begin{tabular}{|c|c|c|}
\hline Degree programme Cluster & Frequency & Percentage \\
\hline $\begin{array}{c}\text { Health/Biological sciences } \\
\text { Engineering/Architecture/Building and } \\
\text { construction }\end{array}$ & 180 & 20.8 \\
\hline $\begin{array}{c}\text { Sciences/ Bachelor of science } \\
\text { Agriculture/ Economics/ Environmental } \\
\text { sciences }\end{array}$ & 150 & 17.3 \\
\hline Computer/Science/Information/Technology & 105 & 4.9 \\
\hline Statistics/Economics/ Programming/Finance & 78 & 2.3 \\
\hline Business/Commerce/Accounting/Administration & 89 & 12.1 \\
\hline Art/ Sociology/ Philosophy/ Anthropology & 10 & 1.2 \\
\hline Law & 116 & 13.4 \\
\hline Education Art & 30 & 3.5 \\
\hline Education Science & 45 & 5.2 \\
\hline TOTAL & 865 & 100 \\
\hline
\end{tabular}

Table 5 clearly indicates that majority $(20.8 \%)$ of the students sample had applied for Health and Biological sciences, followed by Engineering/Architecture/ Building and construction $(17.3 \%)$ Law(13.4\%),Computer/Science/Information/Technology(12.1 $\%)$,Business/Commerce/Accounting(10.2\%) and Statistics/Economics/programming/Finance $(9.0 \%)$. It was a clear indicator that these were most common and famous degree programs the students had applied for as per their choices, representing 82.8 percent, showing a high preference for those courses. Also minority students had applied for Education science (5.2\%), Bachelor of science (4.9\%), Education Art (3.5\%), Agriculture (2.3\%) and Art/sociology/Philosophy/ Anthropology with the least applicants $(1,2 \%)$. From the statistics $(17.2 \%)$ of the total number of minority students had a preference for these degree programmes, showing a less preference for art related courses, agricultural, Education science and Education art.

Despite the laid down career placement policies by KUCCPS based on cluster subjects (Four major subjects that are mandatory) for specific degree programme, cut-off points, mean grade, and capacity of each degree programme in different Universities. Degree programmes have different requirements as per mean grade, cut-off points, clusters and capacity. Also different Universities have different cut-off points, depending on the number of applicants that each programme attracts and capacity of each programme (Ng'ang'a, 2014). The Table 6 shows the distribution of students in each degree programme after placement by KUCCPS in 2018. 
Table 6: Distribution of students by Degree Programmes after placement by KUCCPS

\begin{tabular}{|c|c|c|}
\hline Degree programme Cluster & $\begin{array}{c}\text { Frequenc } \\
\mathrm{y}\end{array}$ & $\begin{array}{c}\text { Percentag } \\
\mathrm{e}\end{array}$ \\
\hline Health/Biological sciences & 38 & 4.4 \\
\hline $\begin{array}{c}\text { Engineering/Architecture/Building and } \\
\text { construction }\end{array}$ & 40 & 4.6 \\
\hline $\begin{array}{c}\text { Sciences/ Bachelor of science } \\
\text { Agriculture/ Economics/ Environmental } \\
\text { sciences }\end{array}$ & 80 & 9.3 \\
\hline Computer/Science/Information/Technology & 36 & 112.9 \\
\hline Statistics/Economics/ Programming/Finance & 37 & 4.3 \\
\hline $\begin{array}{c}\text { Business/Commerce/Accounting/Administrati } \\
\text { on }\end{array}$ & 68 & 7.8 \\
\hline Art/ Sociology/ Philosophy/ Anthropology & 140 & 16.2 \\
\hline Law & 10 & 1.2 \\
\hline Education Art & 204 & 23.6 \\
\hline Education Science & 100 & 11.5 \\
\hline TOTAL & 865 & 100 \\
\hline
\end{tabular}

Table 6 clearly indicates that majority $(23.6 \%)$ of the students sample were enrolled for education arts, followed by art/sociology/Philosophy/ Anthropology (16.2\%), Agricultural/ Economics/Environmental science (12.9\%), Education science $(11.5 \%)$ and Sciences/ bachelor of science $(9.3 \%)$. It was clear indicator that those were most common programmes that the students were placed by KUCCPS representing 72.9 percent. The minority degree programs placements, which are most popular to students, carried the least percentages: Health/Biological sciences(4.4\%),Statistics/Economics/Finance(4.3\%),

Computer/Science/Information/Technology (4.2\%) and Law $(1.2 \%)$. The differences in representation of students in various degree programs can be attributed by laid down policies by KUCCPS based on cluster, cut-off points and capacity of students in each program. Since majority of the students managed to score minimum grades $(\mathrm{C}+\mathrm{B}-$ and $\mathrm{B})$ with low cluster points, they ended up been placed in Art/Sociology/Philosophy/Anthropology, Agricultural courses, Bachelor of science, Education art and sciences, which are of low preference as compared to the rest that require higher cluster points.

When the two samples were correlated; the distribution of students by degree programme as they had applied through KUCCPS before placement is represented as $\mathrm{X}$ and after placement as $\mathrm{Y}$ in Table 7.

\begin{tabular}{|l|l|l|l|l|l|l|l|l|l|l|l|}
\hline $\mathrm{X}$ & 180 & 150 & 42 & 20 & 105 & 78 & 89 & 10 & 116 & 30 & 45 \\
\hline $\mathrm{Y}$ & 38 & 40 & 80 & 112 & 36 & 37 & 68 & 140 & 10 & 204 & 100 \\
\hline
\end{tabular}

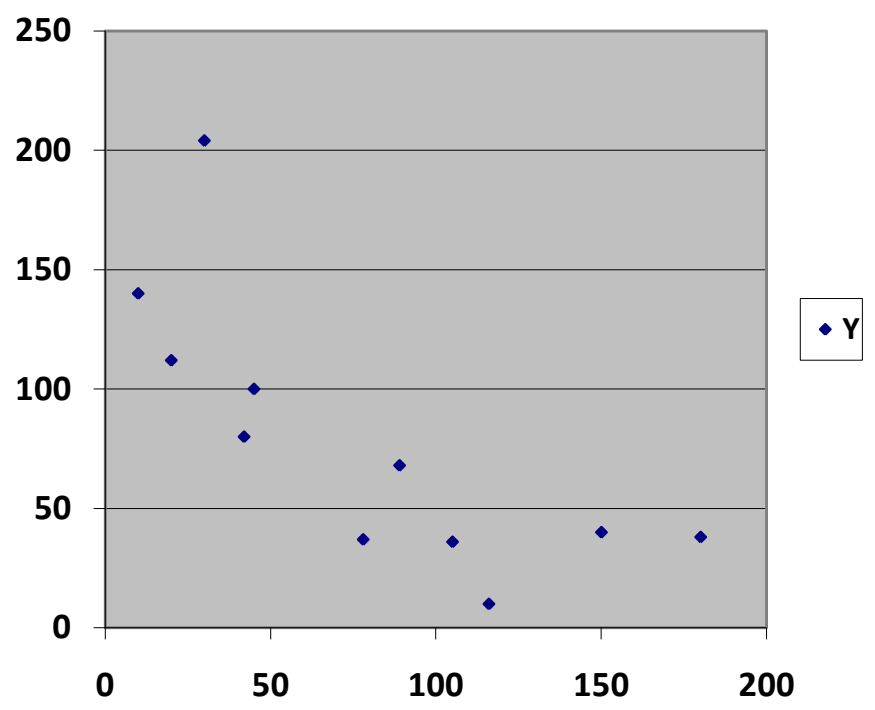

From the Figure 2 the Pearson product-moment correlation coefficient $\left(\gamma_{\mathrm{xy}}\right)$ was -0.75 hence strong negative correlation between variable $\mathrm{X}$ and $\mathrm{Y}$ such that an increase in $\mathrm{X}$ results to a decrease in $\mathrm{Y}$, which means that whatever course the student had applied initially according to their choice, KUCCPS did not place them on their interest, but they were placed in different programs that was not related to their first choice. Therefore, negative correlation.

\subsection{To Investigate the Career Guidance Information from KUCCPS on students' degree Programme Selection Process.}

\subsubsection{Influence of Career Information on Choice of Degree Programme}

The second research objective sought to investigate the influence of career guidance information by KUCCPS on students' degree programme selection process in public universities. The study analyzed statements that assessed how this factor influenced choice of degree programme of students. Influence on career information on degree programme was measured by five items on a likert scale scored as follows; strongly disagree (5), disagree (4), undecided (3), agree (2) and strongly agree (1). The result obtained were represented in the Table 8

Table 8. Influence of career information by KUCCPS on choice of degree programme

\begin{tabular}{|c|c|c|c|c|c|c|c|c|c|c|}
\hline \multirow[t]{2}{*}{ Statement } & \multicolumn{2}{|c|}{ SA } & \multicolumn{2}{|c|}{ A } & \multicolumn{2}{|c|}{$\mathrm{U}$} & \multicolumn{2}{|c|}{$\mathrm{D}$} & \multicolumn{2}{|c|}{ SD } \\
\hline & $\mathrm{F}$ & $\%$ & $\mathrm{~F}$ & $\%$ & $\mathrm{~F}$ & $\%$ & $\mathrm{~F}$ & $\%$ & $\mathrm{~F}$ & $\%$ \\
\hline $\begin{array}{c}\text { I had sufficient information from KUCCPS } \\
\text { concerning my degree programme }\end{array}$ & 118 & 10.6 & 167 & 19.3 & 100 & 11.6 & 178 & 20.6 & 302 & 34.9 \\
\hline $\begin{array}{l}\text { There are many careers related to the degree } \\
\text { course I am studying }\end{array}$ & 484 & 56.0 & 202 & 23.4 & 44 & 5.0 & 65 & 7.5 & 70 & 8.1 \\
\hline
\end{tabular}




\begin{tabular}{|c|c|c|c|c|c|c|c|c|c|c|}
\hline $\begin{array}{l}\text { My school counselor gave me career information } \\
\text { concerning my degree choice as per the } \\
\text { KUCCPS guidelines. }\end{array}$ & 122 & 14.1 & 152 & 17.6 & 96 & 11.1 & 189 & 21.8 & 306 & 35.4 \\
\hline $\begin{array}{c}\text { Career information resources from KUCCPS in } \\
\text { school influenced me in choosing this } \\
\text { Degree programme. }\end{array}$ & 90 & 10.4 & 65 & 7.5 & 70 & 8.1 & 234 & 27.1 & 406 & 46.9 \\
\hline $\begin{array}{l}\text { Many have ever talked to me about degree } \\
\text { Programme I am pursuing. }\end{array}$ & 402 & 46.5 & 108 & 12.5 & 65 & 7.5 & 133 & 15.4 & 157 & 18.2 \\
\hline $\begin{array}{l}\text { I do not know anything about the degree } \\
\text { programme I am studying. }\end{array}$ & 95 & 11.0 & 76 & 8.8 & 54 & 6.2 & 234 & 27.1 & 406 & 46.9 \\
\hline $\begin{array}{c}\text { I was able to access KUCCPS website for } \\
\text { career information and guidance }\end{array}$ & 85 & 9.8 & 136 & 15.7 & 59 & 6.8 & 216 & 25.0 & 369 & 42.7 \\
\hline
\end{tabular}

Table 8 clearly points out that $(55.5 \%)$ of the students disagreed that they had sufficient information from KUCCPS concerning their degree programme while $29.9 \%$ agreed. Majority (56.2) disagreed that they received information from their school counselor as per the KUCCPS guidelines while $31.7 \%$ agreed. Additionally, majority $(74.0 \%)$ disagreed that career information resources from KUCCPS in the school influenced them in choosing the degree programme, while $17.9 \%$ agreed. Majority $(59.0 \%)$ agreed that many had talked to them about the programme they are pursuing while $33.6 \%$ disagreed. Furthermore, majority $(70.0 \%)$ disagreed that they do not know anything about the degree programme they are studying while $19.8 \%$ agreed. However, majority (67.7\%) disagreed that they were able to access KUCCPS website for career information and guidance, while $25.5 \%$ agreed. These findings indicated that there were no sufficient information and resources from KUCCPS that was accessible to schools to guide the students on career programmes. Therefore KUCCPS did not play a significant role in influencing student's choice of career. Students agreed that their school counselors are not well versed with KUCCPS career programme information and therefore not able to guide them well in career selection.

\section{CONCLUSION AND RECOMMENDATION}

\subsection{Conclusion}

Majority of the students scored between B- and B+, which is good grade that allow any student to secure a degree programme of his or her choice in the university. Also 82.8 percent of the students had applied for the most famous degree programmes (Health/biological sciences, Engineering/Architecture, Law, Computer science/technology, Business/commerce/accounting and Statistics/economics/finance) as per their choice, showing a high preference for those courses. But after placement majority of the students $72.9 \%$ were placed in least preference courses (Education/art/sciences, Agriculture, Art/sociology/philosophy/anthropology) different from what they had applied for before placement. Pearson product correlation coefficient of -0.75 , indicated a strong negative correlation in placement of students to degree programmes between what the student had applied for as per their career choice but KUCCPS placed them in different programmes.
The study observed that the level of career guidance provided in the secondary schools was neither well planned nor organized; since 55.5 percent of the students pointed out that they had no sufficient information from KUCCPS concerning their policies on various degree programmes. Also 67.7 percent of the students were not able to access KUCCPS website for career guidance and information. Furthermore, 56.2 percent of the students agreed that they did not get any information on career selection from their school career counselor. In the Kenyan schools, studies indicate that the implementation of career guidance and counseling programme has been hampered by inadequacy of career guidance and counseling resources and unskilled guidance teachers who are overloaded with academic class work (Plank \& Jordan, 2001). KUCCPS as an independence body, given the mandate by the act of the parliament to place students into various career programmes, it should coordinate effectively the placement of students to different career programmes, develop and implement career guidance information to students, disseminate information on available programmes, so that students have the right information when making selection and to avoid them been disappointed after selection and fairing to secure the career of their choice, which has been displayed in the research as majority of the students lacked the right information on career selection at the same time been placed in careers that was not their choice.

\section{RECOMMENDATIONS}

In Kenya public University, not all students admitted under KUCCPS get their preferred degree programmes. Consequently, some students are either satisfied or dissatisfied with the outcome of their degree choice after placement. The students felt that it is not fair for them to be placed in degree programme they never selected because of laid down policies by KUCCPS. They proposed that KUCCPS should be working closely with the labour market each and every year to establish the skill gap for placement where there is a gap and thus making its policy dynamic and not statics or fixed every year. With this kind of strategy most students will benefit and satisfied with the placement. For instance, the study noted that in Health/ Biological sciences careers, placement was done for few students every year yet the country is experiencing challenges in the health sector since the number 
of health workers produced by the universities are not enough to fill the available posts across the country.

The study recommended that career and guidance teachers in secondary schools should be adequately empowered and trained with career guidance skills, knowledge and provided with resources from KUCCPS to carry out effective career guidance services. The schools should work closely with KUCCPS and Universities, which are in position to provide relevant and up-to-date information on how different careers are changing, what grade is needed, subjects clusters required and the best courses for the specific universities. This will help students to best prepare themselves. Further, all secondary schools should be attending University open and career days in which the different faculties and departments explicit the various degree programmes they offer and career opportunities, for students to be versed with skills regarding various degree programmes and the requirements. The students recommended that the school resource centre should be more equipped to support he guidance programme.

\section{ACKNOWLEDGEMENT}

We are grateful and deeply indebted to our family and friends whom this work would have been impossible without their material support. First of all, we thank Almighty God for bringing us this far and providing us with wisdom, guidance, strength and more so focus that has helped us to make this paper a success. We also acknowledge the respondents for their valuable responses and time. To all who made this work a success, we thank you all.

\section{REFERENCES}

[1] Agrey, L., \& Lampadan, N. (2014). Determinant Factors Contributing to Students" Choice in Selecting University. Journal of Education and Human Development. Vol 3(2), 391-404.

[2] Alfred-Davidson, T. 2009.High school counselor and career specialists' perceptions of school practices that involve parents in students' career planning. PhD Diss., Dept. of Secondary Univ of Florida. United States, Florida.

[3] Banks-Santilli,L. (2014). First Generation College Students and their Pursuit of the American Dream. Journal of case studies in Higher Education, 5,1-32. American Press.

[4] Brown, D., and Brooks,.L. (1991). Career Couselling Techniques. Needham Heights, MA:Allyn \& Bacon.

[5] Gaffner, D.C., \& Hazler, R.J.(2002). Factors Related to Indecisiveness and Career Indecision in Undecided College Students. Journal of College Students Development, 43, 317-326.

[6] Gibson, R. L., \& Mitchell, M. H. (2003). Introduction to Guidance and Counselling. (6th ed). New York: Pearson Educational Inc.

[7] Jomo Kenyatta University, (2018). Admission Office: Career Selection and Placement, Handbook of the College Admissions Profession, University Press. Kenyan Association of College Registrars and Admission.
[8] Kenyatta University, (2018). Admission Office: Career Selection and Placement, Handbook of the College Admissions Profession, University Press. Kenyan Association of College Registrars and Admission.

[9] Kidd, H. (2007) and Savickas, M. (2005). Career Construction Principals and Practice, Handbook of Vocational Psychology $\left(4^{\text {th }}\right.$ edn).....33-52 page 33 .

[10] Mugenda, O. \& Mugenda, A. (2003). Research methods Quatitative and Qualitative Approach. Nairobi Acts Press.

[11] Muindi, B. (2011, February 22nd). Scrap Parallel Degree Courses, Says Mwiria. The Daily Nation. Retrieved on 1st March, 2011 from: Daily Nation On The Web.

[12] Mutero, D. (2001, May 14). Not all is Lost in Public Universities. The Daily Nation, (20). Nairobi: Nation Media Group Ltd.

[13] Mutie \& Ndambuki, P. (2002). Guidance and Counselling for School and Coleges. Nairobi: Oxford University press.

[14] Ng'ang'a. A, (2014). Effect of Talent Management on Organisation Performance Case of Conservation Agency in Kenya. International Journal of social sciences Management and Entrepreneurship 2(1):241-261, April 2018. Sage Publishers.

[15] Onsongo. J. (2011). Affirmative Action, Gender Equity and University Admission-Kenya, Uganda and Tanzania. London Review of Education. Vol 7, No1, March 2009, 71-81.

[16] Onsongo, J. (2009) . Four forms of Disconnection:Negociating Gender, Education and Poverty Reduction in Schools in Kenya and South Africa. Assets Publishing Service.gov.uk.

[17] University of Nairobi (2018). Admission Office: Career Selection and Placement, Handbook of the College Admissions Profession, University Press. Kenyan Association of College Registrars and Admission.

[18] Plank, S. B., \& Jordan, W. J. (2001). Effects of information, guidance, and actions on postsecondary destinations: A study of talent loss. American educational research Journal, 38(4), 947979.

[19] Porter, S.R. and P.D. Umbach. 2006. College major choice: An analysis of person-enviroment. Research in Higher Education. 47(4):429-449.

[20] Swan, C. C. (1998). Admissions officer: A profession and a career. In C. Swan \& S. Henderson (Eds.), Handbook for the college admissions profession (pp. 29-36). Westport, CT:Greenwood Press, American Association of Collegiate Registrars and Admission Officers.

[21] Trusty, J, S.G. Niles, and J.V. Carney. 2005. Education-career planning and middle school counselors. Professional School Counseling. 9(2):136-143

\begin{tabular}{|c|c|}
\hline \multirow{2}{*}{ AUTHOR } & $\begin{array}{c}\text { KARANJA JOSEPH NDUNG'U } \\
\text { DOCTOR OF EDUCATION STUDENT IN } \\
\text { THE SCHOOL OF EDUCATION } \\
\text { ADMINISTATION AND PLANNING.- } \\
\text { University of Nairobi }\end{array}$ \\
\hline CO-AUTHOR & $\begin{array}{c}\text { DR. ROSE OBAE (Senior Lecturer) } \\
\text { Lecturer, School of Education } \\
\text { Administration and Planning in University } \\
\text { of Nairobi }\end{array}$ \\
\hline
\end{tabular}

